\title{
A Retrospective Analysis of the Real-Life Utilization of Ranibizumab in Patients with Wet Age-Related Macular Degeneration from Portugal
}

\author{
Análise Retrospetiva Sobre a Utilização em Contexto Real \\ do Ranibizumab em Doentes com Degenerescência Macular \\ da Idade Exsudativa em Portugal
}

Rufino SILVA $\bigotimes^{1,2,3}$, Carla GONCALVES ${ }^{4}$, Angelina MEIRELES ${ }^{5}$, Carla TEIXEIRA ${ }^{6}$, Paulo ROSA ${ }^{7}$, Manuel MONTEIRO-GRILLO ${ }^{8}$, Joaquim CANELAS ${ }^{8}$, Ângela CARNEIRO ${ }^{9,10}$, Rita FLORES ${ }^{11}$

Acta Med Port 2017 Jun;30(6):449-456 - https://doi.org/10.20344/amp.8217

\begin{abstract}
Introduction: Anti-vascular endothelial growth factor therapy has revolutionized the treatment of wet age-related macular degeneration; however, it is important to monitor actual use of ranibizumab and related treatment outcomes in routine practice.

Material and Methods: This was a retrospective, observational study to monitor the 2-year outcomes following ranibizumab treatment for wet age-related macular degeneration in Portugal. Patients treated between January 2009 and December 2009 were retrospectively evaluated. All decisions were made by the treating physician in accordance with their usual routine clinical practice. The primary assessment was mean change in visual acuity score using Early Treatment Diabetic Retinopathy Study or Snellen equivalent.

Results: A total of 128 patients with wet age-related macular degeneration were analyzed (mean age 79.4 years; mean visual acuity score 54.2 letters). Mean change in visual acuity score from baseline was -1.6 letters $(n=82)$ at year one and -5.1 letters $(n=72)$ at year two. The mean number of ranibizumab injections was 3.8 (year one) and 1.6 (year two). On average, patients attended 8.6 and 5.0 visits and optical coherence tomography was used in $75.0 \%$ of patients in year one and in $56.3 \%$ of patients in year two, respectively. Discussion: Despite a relatively high number of visits, including monitoring visits and use of optical coherence tomography - guided therapy, few injections were administered and visual acuity was not improved.

Conclusion: These findings indicate that as-needed treatment resulted in under-dosing in a real-life setting in Portugal. Such limitations may also be related to increasing numbers of patients, resulting in clinic saturation.
\end{abstract}

Keywords: Portugal; Ranibizumab; Visual Acuity; Wet Macular Degeneration

\section{RESUMO}

Introdução: A terapeutica com anti-factor de proliferação endotelial vascular revolucionou o tratamento da degenerescência macular da idade exsudativa; no entanto, é importante monitorizar o uso em contexto real do ranibizumab e os resultados associados ao tratamento na prática clínica corrente.

Material e Métodos: Este foi um estudo observacional, retrospetivo, para monitorizar os resultados de dois anos, após o tratamento com ranibizumab para a da degenerescência macular da idade exsudativa em Portugal. Os doentes tratados entre janeiro de 2009 e dezembro de 2009 foram avaliados retrospetivamente. Todas as decisões foram tomadas pelo médico responsável pelo tratamento, em conformidade com a respetiva prática clínica corrente. A avaliação primária foi a alteração média na melhor acuidade visual corrigida utilizando a tabela ETDRS (Early Treatment of Diabetic Retinopathy Study) ou Snellen equivalente.

Resultados: Foi analisado um total de 128 doentes com degenerescência macular da idade exsudativa (idade média de 79,4 anos; média de acuidade visual de 54,2 letras). A alteração média na melhor acuidade visual corrigida desde a situação basal foi de $-1,6$ letras $(n=82)$ no ano um e $-5,1$ letras $(n=72)$ no ano dois. O número médio de injeções de ranibizumab foi de 3,8 (ano um) e 1,6 (ano dois). Em média, os doentes tiveram entre 8,6 e 5,0 consultas e foi utilizada a tomografia de coerência ótica em $75,0 \%$ dos doentes no ano um e em $56,3 \%$ dos doentes no ano dois, respetivamente.

Discussão: Apesar do número de consultas relativamente elevado, incluindo consultas de monitorização e de utilização de terapêutica guiada por tomografia de coerência ótica, foram administradas poucas injeções e não houve melhoria na acuidade visual.

Conclusão: Em Portugal, num contexto real, estes achados indicam que o tratamento consoante as necessidades resultou numa dosagem insuficiente. Essas limitações também podem estar associadas ao número crescente de doentes, o que resulta numa saturação clínica.

Palavras-chave: Acuidade Visual; Degenerescência Macular Exsudativa; Factores de Tempo; Portugal; Ranibizumab

\footnotetext{
1. Department of Ophthalmology. Faculdade de Medicina. Universidade de Coimbra. Coimbra. Portugal.

2. Department of Ophthalmology. Centro Hospitalar e Universitário de Coimbra. Coimbra. Portugal.

3. Association for Innovation and Biomedical Research on Light and Image. Coimbra. Portugal.

4. Bayer Portugal. Carnaxide. Portugal.

5. Department of Ophthalmology. Centro Hospitalar do Porto. Porto. Portugal.

6. Department of Ophthalmology. Unidade Local de Saúde de Matosinhos. Matosinhos. Portugal.

7. Department of Ophthalmology. Instituto Oftalmológico Gama Pinto. Lisboa. Portugal.

8. Department of Ophthalmology. Centro Hospitalar de Lisboa Norte. Lisboa. Portugal.

9. Department of Sense Organs. Faculdade de Medicina. Universidade do Porto. Porto. Portugal.

10. Department of Ophthalmology. Hospital de São João. Porto. Portugal.

11. Department of Ophthalmology. Centro Hospitalar de Lisboa Central. Lisboa. Portugal.

$\square$ Autor correspondente: Rufino Silva. rufino.silva@oftalmologia.co.pt

Recebido: 14 de setembro de 2016 - Aceite: 27 de fevereiro de 2017 | Copyright @ Ordem dos Médicos 2017
} 


\section{INTRODUCTION}

Anti-vascular endothelial growth factor (anti-VEGF) therapy has revolutionized the treatment of wet agerelated macular degeneration (WAMD), and its widespread introduction may be associated with a decrease in the incidence of legal blindness. ${ }^{1}$ Intravitreal ranibizumab was approved for use in this chronic degenerative condition, largely based on the outcomes from the two key registry studies (ANCHOR [ANti-VEGF antibody for the treatment of predominantly classic $\mathrm{CHORoidal}$ neovascularization in age-related macular degeneration] and MARINA [Minimally classic/occult study of the Anti-VEGF antibody Ranibizumab In the treatment of Neovascular Age-related macular degeneration]). ${ }^{2,3}$ In these studies, mean visual acuity improved by 11.3 and 7.2 letters, respectively, at 12 months with monthly use of intravitreal ranibizumab $0.5 \mathrm{mg}$.

However, a number of alternative regimens, including as-needed dosing, have also been proposed and are widely used in clinical practice. ${ }^{4-8}$ Results from clinical studies indicate that outcomes are more variable with lessfrequent intravitreal ranibizumab dosing. ${ }^{9-11}$ LUMIERE, a retrospective observational study of 551 patients with WAMD, showed that poor compliance with intravitreal ranibizumab was associated with loss of initial treatment gains over a 12 - month period, from 5.3 letters at month three to 3.2 letters at month 12. In LUMIERE, less than $40 \%$ of patients received three initial monthly injections, and the mean number of injections was 5.1 over the 12 - month period. ${ }^{4}$

In another retrospective real-world study (AURA; A retrospective non-interventional study to assess the effectiveness of existing anti-VEGF treatment Regimens in patients with WAMD), the mean change in visual acuity decreased from +2.4 letters (year one) to +0.6 letters (year two) in patients with WAMD who received an average of 5.0 and 2.2 intravitreal ranibizumab injections in year one and year two, respectively. ${ }^{6}$ AURA was conducted in eight countries, but did not include Portugal. The aim of this study, which was based on the AURA design, was to determine the real-life utilization and associated outcomes following intravitreal ranibizumab use in WAMD patients from Portugal.

\section{MATERIAL AND METHODS}

\section{Study design and patients}

This was a retrospective, multicenter, non-interventional, observational study (NCT01933152) to monitor the reallife use and related outcomes following treatment with intravitreal ranibizumab for WAMD in patients from clinical practices in Portugal (Centro Hospitalar do Porto, Unidade Local de Saúde de Matosinhos, Centro Hospitalar de Lisboa Norte, Instituto Oftalmológico Gama Pinto and Centro Hospitalar e Universitário de Coimbra). We collected data retrospectively from medical records of treatment-naïve patients who were diagnosed with WAMD and prescribed intravitreal ranibizumab between 01 January 2009 and 31 December 2009. We collected data for up to three years, with the final data collection on 30 April 2013 (Fig. 1); however, we report only outcomes at year one and year two. The 3-year data are not presented due to low follow-up at this point.

The treating physicians made all diagnoses and subsequent decisions to treat (including dose and duration) in accordance with their usual routine clinical practice. This was based on WAMD treatment guidelines and the indication for ranibizumab at the time of the study, which included monthly or as-needed dosing after a loading phase. All centers used an as-needed regimen, and the proportion of patients who received a loading phase was recorded. All treating physicians were sufficiently trained on the background and objectives of the study, protocol and procedures, use of the electronic case report form (to collect retrospective data), and ethical as well as regulatory obligations. The study was performed in accordance with the Declaration of Helsinki (2008). Approval from the relevant independent ethics committee was obtained. All patients provided written informed consent. Eligible patients were documented using the electronic case report form. Patients who had participated in an investigational study of any other drug or device during the treatment period from start to 31 December 2011 were excluded.

\section{Study assessments}

Our primary objective was to evaluate the mean change in visual acuity score (VAS) after treatment with intravitreal ranibizumab (using ETDRS or Snellen equivalent). Secondary objectives were to monitor resource utilization (i.e., number of visits [total, clinic, and monitoring] and intravitreal ranibizumab injections) after the start of therapy, including outcomes from diagnostic tests, and to determine the socio-demographic profile of the patients diagnosed

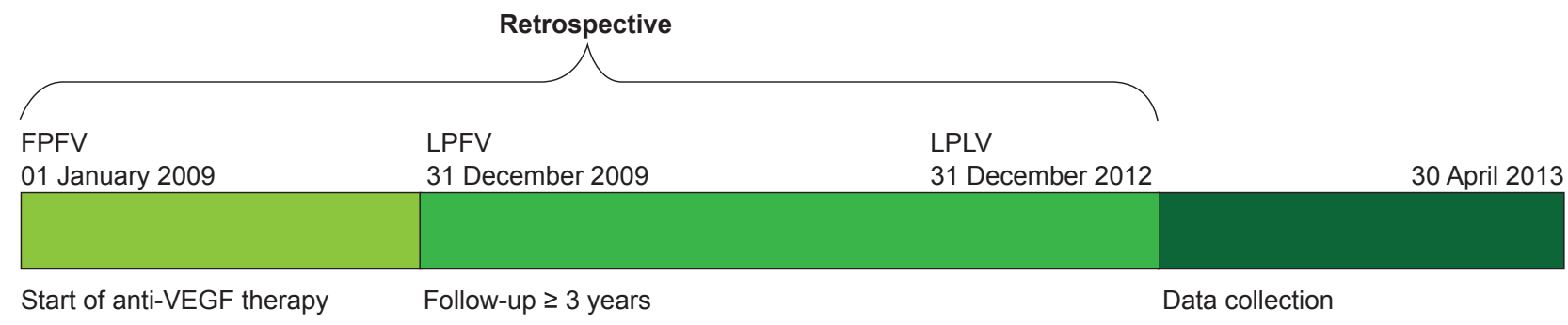

Figure 1 - Study design and timeline

FPFV: First patient first visit; LPFV: Last patient first visit; LPLV: Last patient last visit; VEGF: Vascular endothelial growth factor. 
with wAMD. We retrospectively evaluated data from patient medical records and the results from any routine examinations and assessments.

\section{Statistical analyses}

Our study was explorative; there were no formal hypotheses. We calculated that a sample size of 200 patients was needed to estimate, within a $95 \%$ confidence interval, the change in visual acuity from baseline (based on the ETDRS letter score) in patients being treated with anti-VEGF therapy with a margin of error of 2.0 letters. A standard deviation (SD) of 14.4 for the change in visual acuity was assumed based on the values observed for ranibizumab $0.5 \mathrm{mg}$ every four weeks in the VIEW 1 and VIEW 2 (VEGF Trap-Eye: investigation of efficacy and safety in wAMD) studies. ${ }^{12,13}$

We used the exposed population (i.e., patients who received $\geq 1$ intravitreal ranibizumab injection) as the basis for our analyses. For change in visual acuity, we used two methods of analysis: method one, taking into consideration the visit with the information nearest to 360 days, within 300 and 420 days after the first injection, or the information nearest to 720 days, within 660 and 780 days after the first injection, and method two, taking into consideration the mean change in visual acuity to the mean value observed within 300 and 420 days after the first injection or within 660 and 780 days after the first injection.

For the primary outcome (i.e., mean change in VAS), if ETDRS letter scores (or equivalent notations) were not available, then we converted the approximate Snellen acuity equivalent to VAS. When Snellen had no equivalence with VAS, we considered the lowest visual acuity. We analyzed VAS using observed data (i.e., missing values were not replaced) and via a last observation carried forward (LOCF) analysis, which accounted for missing data. For analysis of mean change in VAS from baseline (date of the start of intravitreal ranibizumab therapy or date of diagnosis if unavailable) to year one and year two, we used a SIGN test (this analysis was not adjusted for missing data). Statistical tests were 2-tailed, considering a significance level of $5 \%(p<0.05)$. For analysis of secondary outcomes, we used frequency tables for categorical variables and sample statistics for continuous variables. For all secondary analyses, missing values were not replaced, and any percentages were calculated based on non-missing values. We performed statistical analyses using SAS version 9.2 (SAS Institute Inc, Cary, North Carolina, USA).

\section{RESULTS \\ Patients}

We screened a total of 257 patients; however, 129 patients were not eligible for participation and were excluded due to the following reasons: lost to follow-up $(n=76)$, death $(n=32)$, refusal to participate $(n=10)$, change of treating physician ( $n=4)$, unable to be contacted or had changed address $(n=5)$, unable to provide written informed consent

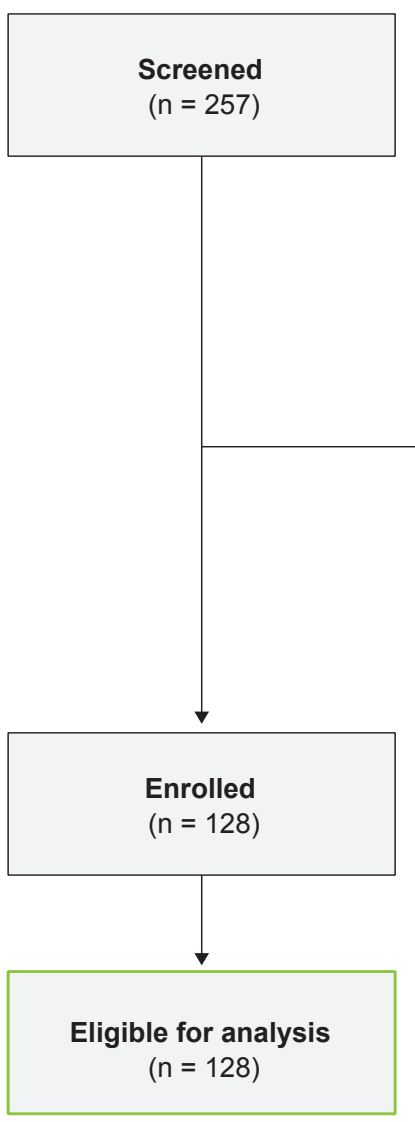

\section{Excluded}

$(n=129)$

- Lost to follow-up $(n=76)$

- Death $(n=32)$

- Refusal to participate $(n=10)$

- Change of treating physician $(n=4)$

- Unable to be contacted $(n=5)$

- Unable to provide written informed consent $(n=1)$

- Unable to provide written informed consent / hypoacusis $(n=1)$

Figure 2 - Patient flow diagram 
(1), and unable to provide written informed consent and presented with marked hypoacusis (1). A total of 128 patients were enrolled and eligible for analysis (Fig.2). The baseline characteristics of the exposed population $(n=128)$ are summarized in Table 1 . The mean (SD) age was $79.4(7.9)$ years and $62.5 \%$ were female. Study (treated) eye was the right eye for $57.0 \%$ of patients and the left eye for $43.0 \%$ of patients. The mean (SD) time from diagnosis to first intravitreal ranibizumab injection was 73.4 (220.0) days. The mean (SD) time from first injection to last follow-up visit was 712.0 (277.1) days. The time in study ranged from 36 - 1072 days.

\section{Change in VAS}

Using method one, the mean change in VAS (letters)

Table 1 - Baseline characteristics (exposed population [ $n=128]$ )

\begin{tabular}{|c|c|}
\hline Characteristic & Exposed population \\
\hline Age, years, mean (SD) & $79.4(7.9)$ \\
\hline \multicolumn{2}{|l|}{ Sex, n (\%) } \\
\hline Male & $48(37.5)$ \\
\hline Female & $80(62.5)$ \\
\hline \multicolumn{2}{|l|}{ Eye affected by wAMD, n (\%) } \\
\hline Right & $89(69.5)$ \\
\hline Left & $78(60.9)$ \\
\hline \multicolumn{2}{|l|}{ FA performed at diagnosis, $\mathrm{n}(\%)$} \\
\hline Yes & $74(57.8)$ \\
\hline No & $54(42.2)$ \\
\hline \multicolumn{2}{|l|}{ CNV lesion type, $n(\%)[n=74]$} \\
\hline Classic & $17(23.0)$ \\
\hline Classic and occult & $15(20.3)$ \\
\hline Occult & $27(36.5)$ \\
\hline Disciform scar & $1(1.4)$ \\
\hline None & $2(2.7)$ \\
\hline Unknown & $12(16.2)$ \\
\hline CRT, $\mu \mathrm{M}$, mean (SD) & $245.5(116.0)$ \\
\hline \multicolumn{2}{|l|}{ Visual acuity tests, $\mathrm{n}(\%)$} \\
\hline No & $7(5.5)$ \\
\hline Yes & $121(94.5)$ \\
\hline $\begin{array}{l}\text { Visual acuity score, }{ }^{*} \\
\text { letters, mean }(S D)[n=82]\end{array}$ & $54.2(19.6)$ \\
\hline $\begin{array}{l}\text { Intraocular pressure, } \\
\text { mmHg, mean (SD) }\end{array}$ & $16.1(3.1)$ \\
\hline Concomitant medication, n (\%) & $98(76.6)$ \\
\hline \multicolumn{2}{|c|}{ Concomitant medication indication (> 15\%), n (\%) } \\
\hline Arterial hypertension & $81(82.7)$ \\
\hline Dyslipidemia & $30(30.6)$ \\
\hline Diabetes mellitus & $21(21.4)$ \\
\hline Glaucoma & $18(18.4)$ \\
\hline Depression & $15(15.3)$ \\
\hline
\end{tabular}

* ETDRS and Snellen at baseline (start of treatment or diagnosis).

CNV: Choroidal neovascularization; CRT: Central retinal thickness; FA: Fluorescein angiography; SD: Standard deviation; WAMD: Wet age-related macular degeneration. from baseline was -1.6 letters (from a mean [SD] score of 54.2 [19.6] at baseline [start of therapy or diagnosis] to 52.6 [22.8]; $n=82$ ) at year one and -5.1 letters (from a mean [SD] score of 52.5 [20.4] at baseline to 47.4 [25.0]; $\mathrm{n}=72$ ) at year two; these changes were not statistically significant ( $p=0.43$ and $p=0.80$, respectively) (Fig. 3A). Using method two, the mean change in VAS (letters) from baseline was -1.98 letters (year one) and -5.11 letters (year two). A total of 120 patients were included in the LOCF analysis, and the mean change in VAS (using the LOCF approach) from baseline was -1.88 letters (year one) and -5.56 letters (year two) (Fig. 3B).

\section{Resource utilization}

Visits: The mean number of clinic visits (when patients received treatment), monitoring visits (when patients did not receive treatment), and total visits (clinic and monitoring visits) attended during year one and year two is shown in Fig. 4A. There was a decrease in total visits from 8.6 in year one to 5.0 in year two. The mean number of clinic visits was low, decreasing from 3.7 (year one) to 1.6 (year two), and monitoring visits decreased from 4.9 (year one) to 3.5 (year two).

Injections: The mean number of injections received during year one and year two is shown in Fig. 4A. In the first year, the mean number of injections administered was 3.8 , decreasing to 1.6 in year two. Within the first 125 days, $38.3 \%$ of patients received three injections (loading phase) and $4.7 \%$ received four injections.

Diagnostic tests: The most commonly used test was optical coherence tomography (OCT), used in $75.0 \%$ of patients in year one and in $56.3 \%$ of patients in year two (Fig. 4B). Most clinics used spectral-domain OCT at diagnosis $(77.6 \%)$, year one $(80.2 \%)$, and year two $(88.9 \%)$. Despite an initial decrease in subretinal fluid, there was a marked increase in physician-reported cases of subretinal fluid from $29.2 \%$ in year one to $39.4 \%$ in year two (Table 2). Physicianreported geographic atrophy on OCT was documented in $7.1 \%$ of patients at diagnosis, $14.1 \%$ of patients at year one, and $20.6 \%$ of patients at year two. Ophthalmoscopy showed that vitreous body and optic nerve head findings were normal for the majority of patients throughout the study (Table 2). Mean intraocular pressure was $16.1 \mathrm{mmHg}$ at diagnosis and approximately $14 \mathrm{mmHg}$ for years one and two (Table 2).

\section{Reasons for study discontinuation}

Overall, 35 patients discontinued the study. Of these, 32 patients discontinued due to permanent discontinuation of anti-VEGF therapy, and three patients discontinued due to other reasons (Table 3 ). In patients who permanently discontinued treatment, the main reason was investigatordriven criteria $(n=19)$. When the discontinuation was based on a decision taken by the investigator (e.g., not lost to follow-up), the main reason for discontinuation of antiVEGF therapy (59\%) was treatment failure. 
A

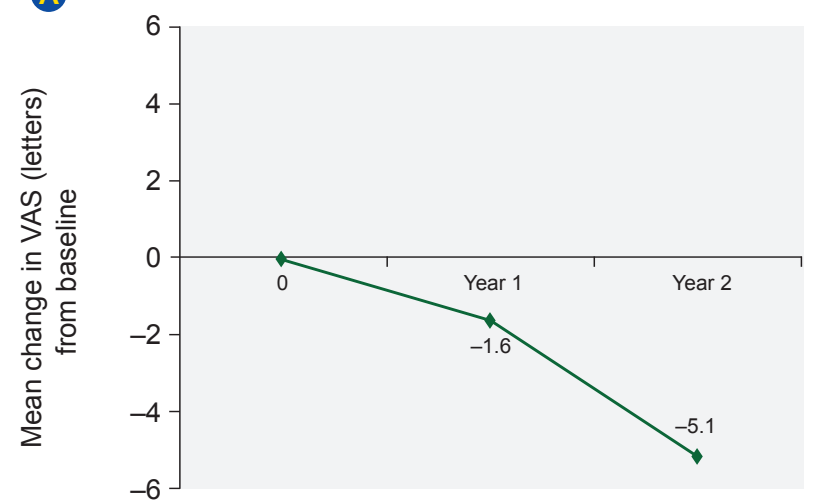

B

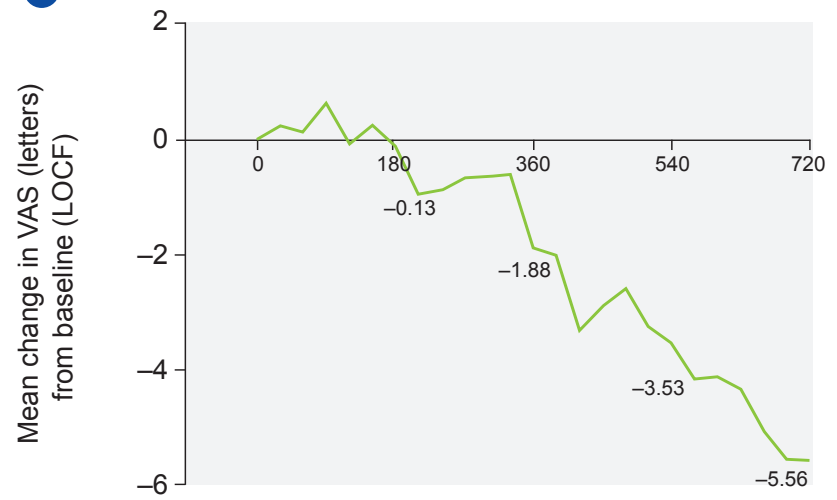

Figure 3 - Mean change in visual acuity score from baseline over the 2-year period in the exposed population (A) with no adjustment for missing data $(n=128)$ and $(B)$ using a LOCF approach $(n=120)$

LOCF: Last observation carried forward; VAS: Visual acuity score
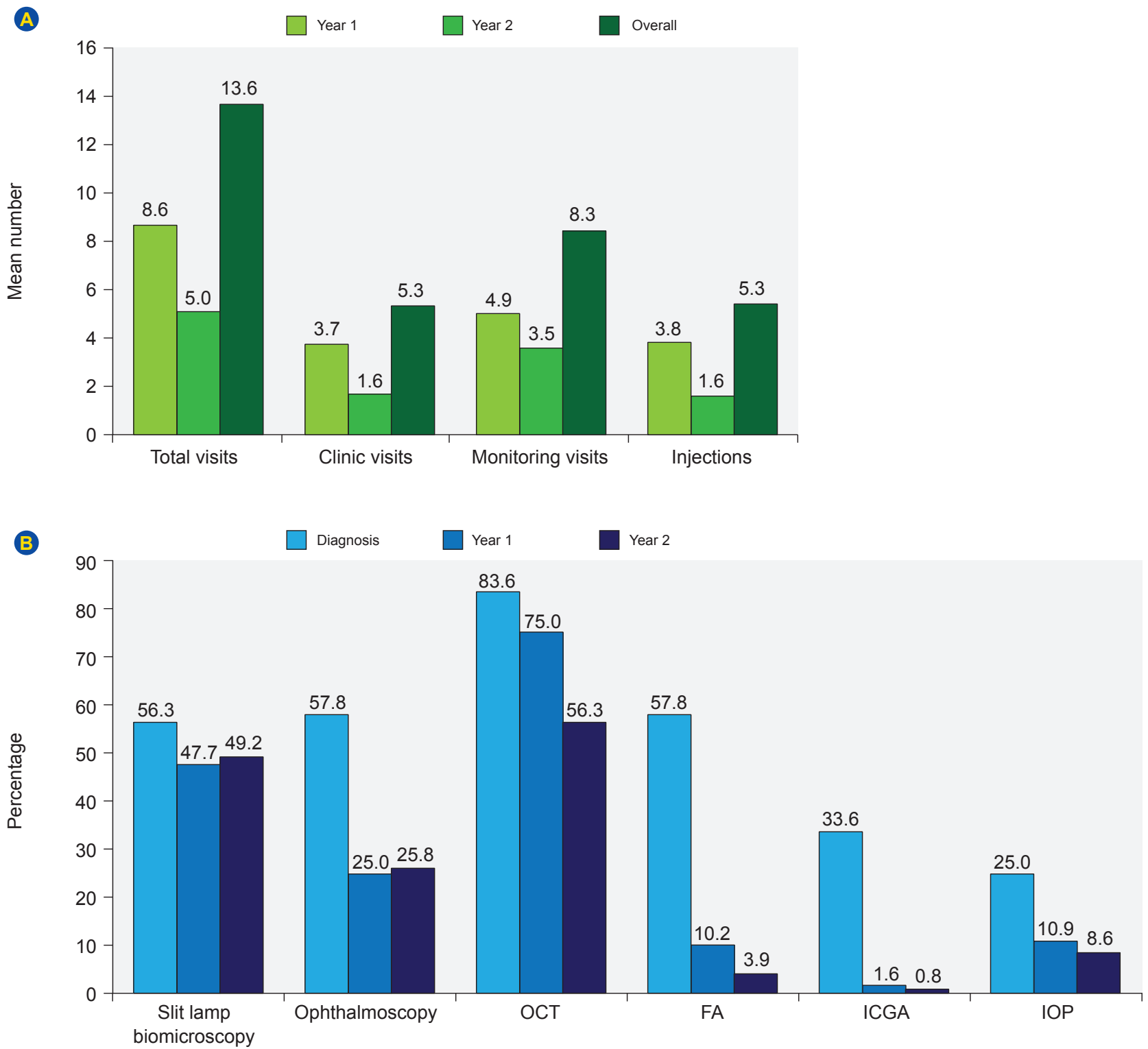

Figure 4 - (A) Mean number of visits and intravitreal ranibizumab injections in year one ( $\leq 365$ days) and year two (> 365 and $\leq 730$ days) and $(B)$ mean number of diagnostic tests performed in year one and year two in the exposed population $(n=128)$

FA: Fluorescein angiography; ICGA: Indocyanine green angiography; IOP: Intraocular pressure; OCT: Optical coherence tomography. 
Table 2 - Key outcomes of diagnostic tests performed (exposed population [n = 128])

\begin{tabular}{|c|c|c|c|}
\hline Test/key outcome & Diagnosis & Year one & Year two \\
\hline \multicolumn{4}{|l|}{ Ophthalmoscopy } \\
\hline \multicolumn{4}{|l|}{ Vitreous body, n (\%) } \\
\hline Normal & $60(98.4)$ & $28(100.0)$ & $27(96.4)$ \\
\hline Abnormal & $1(1.6)$ & 0 & $1(3.6)$ \\
\hline \multicolumn{4}{|l|}{ Optic nerve head, n (\%) } \\
\hline Normal & $48(100.0)$ & $18(94.7)$ & $18(90.0)$ \\
\hline Abnormal & 0 & $1(5.3)$ & $2(10.0)$ \\
\hline \multicolumn{4}{|l|}{ ОСт } \\
\hline CRT, $\mu \mathrm{m}$, mean (SD) & $\begin{array}{c}245.5(116.0) \\
{[n=14]}\end{array}$ & $\begin{array}{c}213.6(39.1) \\
{[n=11]}\end{array}$ & $\begin{array}{c}180.0(76.4) \\
{[n=2]}\end{array}$ \\
\hline Total volume, $\mathrm{mm}^{2}$, mean (SD) & $\begin{array}{l}9.6(2.6) \\
{[n=75]}\end{array}$ & $\begin{array}{l}9.2(1.7) \\
{[n=65]}\end{array}$ & $\begin{array}{l}8.8(1.9) \\
{[n=54]}\end{array}$ \\
\hline \multicolumn{4}{|l|}{ Subretinal fluid, n (\%) } \\
\hline No & $49(47.6)$ & $63(70.8)$ & $43(60.6)$ \\
\hline Yes & $54(52.4)$ & $26(29.2)$ & $28(39.4)$ \\
\hline \multicolumn{4}{|l|}{ Geographic atrophy, n (\%) } \\
\hline No & $91(92.9)$ & $73(85.9)$ & $50(79.4)$ \\
\hline Yes & $7(7.1)$ & $12(14.1)$ & $13(20.6)$ \\
\hline \multicolumn{4}{|l|}{ Fluorescein angiography } \\
\hline Area of total lesion, $\mathrm{mm}^{2}$, mean (SD) & $\begin{array}{c}28.5(23.1) \\
{[n=42]}\end{array}$ & $\begin{array}{c}25.7(29.9) \\
{[n=6]}\end{array}$ & $\begin{array}{c}1.8(0.5) \\
{[n=2]}\end{array}$ \\
\hline Area of $\mathrm{CNV}, \mathrm{mm}^{2}$, mean (SD) & $\begin{array}{c}14.5(14.5) \\
{[n=22]}\end{array}$ & $\begin{array}{c}48.1(52.1) \\
{[n=2]}\end{array}$ & $\begin{array}{c}1.8(0.5) \\
{[n=2]}\end{array}$ \\
\hline \multicolumn{4}{|l|}{ Indocyanine green angiography } \\
\hline \multicolumn{4}{|l|}{ PCV, n (\%) } \\
\hline No & $35(87.5)$ & 0 & 0 \\
\hline Yes & $5(12.5)$ & $2(100.0)$ & $1(100.0)$ \\
\hline \multicolumn{4}{|l|}{ RAP, n (\%) } \\
\hline No & $32(78.0)$ & $2(100.0)$ & $1(100.0)$ \\
\hline Yes & $9(22.0)$ & 0 & 0 \\
\hline \multicolumn{4}{|l|}{ Intraocular pressure } \\
\hline Intraocular pressure, mmHg, mean (SD) & $\begin{array}{c}16.1(3.1) \\
{[n=32]}\end{array}$ & $\begin{array}{c}14.3(3.7) \\
{[n=14]}\end{array}$ & $\begin{array}{c}14.2(2.4) \\
{[n=11]}\end{array}$ \\
\hline
\end{tabular}

CNV: Choroidal neovascularization; CRT: Central retinal thickness; OCT: Optical coherence tomography; PCV: Polypoidal choroidal vasculopathy; RAP: Retinal anastomoses proliferation; SD: Standard deviation.

\section{DISCUSSION}

The primary objective of our study was to evaluate changes in visual acuity during the first and second years after the introduction of anti-VEGF therapy with intravitreal ranibizumab in patients from Portugal. The mean change in visual acuity from the start of intravitreal ranibizumab therapy or diagnosis was -1.6 letters at year one and -5.1 letters at year two, which were not statistically significant compared with baseline. Similar findings were also observed using a LOCF approach, where mean changes were -1.9 letters (year one) and -5.6 letters (year two). On average, patients attended 8.6 visits during year one and 5.0 visits during year two. The majority of patients underwent OCT at year one and year two time points $(75.0 \%$ and $56.3 \%$, respectively). However, the mean number of intravitreal ranibizumab injections was very low, with patients receiving
3.8 injections during year one and 1.6 injections during year two. It is noteworthy that the proportion of patients with subretinal fluid increased from year one to year two (from $29.2 \%$ to $39.4 \%$ ). Geographic atrophy was identified in $7.1 \%$ of patients upon diagnosis, increasing to $20.6 \%$ at two years, which we might speculate to be related to the underlying dry AMD.

In the global AURA study, the mean change in VAS was +2.4 letters (5.0 injections and 8.6 visits) in year one and +0.6 letters (2.2 injections and 4.9 visits) in year two using a LOCF approach. ${ }^{6}$ AURA also showed that the mean change in VAS was lowest in Italy, where the changes were 0 letters (3.8 ranibizumab injections and 8.5 visits) at year one and -2.9 letters (1.2 ranibizumab injections and 4.2 visits) at year two. The mean change in VAS was highest in the UK, where the changes were +6.0 letters (5.8 ranibizumab 
Table 3 - Reasons for study discontinuation (exposed population [ $\mathrm{n}=128]$ )

\begin{tabular}{lc}
\hline Reasons & Exposed population \\
\hline Study completers & $93(72.7)$ \\
Discontinuations & $32(25.0)$ \\
Permanent discontinuation of anti-VEGF therapy & $1(0.8)$ \\
Withdrawal by patient & $2(1.6)$ \\
Other & $19(59.4)$ \\
Reasons for permanent discontinuation of anti-VEGF therapy, $\mathrm{n}(\%)[\mathrm{n}=32]$ & $13(40.6)$ \\
Investigator-driven criteria & $1(3.1)$ \\
Other & $1(3.1)$ \\
Drug switching, $\mathrm{n}(\%)$ [n $=32]$ & \\
Bevacizumab & \\
Photodynamic therapy & \\
\hline
\end{tabular}

VEGF: Vascular endothelial growth factor

injections and 10.4 visits) at year one and +4.1 letters $(3.2$ ranibizumab injections and 8.0 visits) at year two. ${ }^{6}$

In our study, visual acuity declined over a 2-year followup period. These findings are generally consistent with a smaller Portuguese observational study of 77 patients with wAMD (84 eyes) who were treated with intravitreal ranibizumab over a 3 -year period. ${ }^{14}$ At three years, the mean number of treatments was 8.6, but improvements in visual acuity were not maintained over time as only $15.4 \%$ presented a gain of $\geq 15$ letters in BCVA and $61.5 \%$ experienced stabilization of BCVA loss (i.e., visual loss of $<5$ letters). In the COMPASS study, which was an observational study of 1729 evaluable patients with wAMD in Germany, patients received 4.5 injections (three injections during a 3-month loading phase and 1.5 additional injections during a 12-month maintenance phase) over a 15-month period, and despite initial gains during the loading phase, patients' visual acuity declined thereafter. ${ }^{7}$ These authors argued that a flexible and predominantly visual acuity-driven retreatment regimen results in a loss of visual acuity, which is consistent with other studies. ${ }^{15}$ Although our study showed this decline in visual acuity over time, there were very little initial gains compared with other observational studies, which may be related to the lack of a loading phase, with less than $50 \%$ of patients receiving three injections during the first 125 days, and low number of injections overall. It must also be noted that there was a delay between diagnosis and start of treatment; the mean time was 73.4 days. Although the reasons for this are not known, and may be related to patient choice, referral, or reimbursement issues, this delay may have affected outcomes.

The treatment outcomes in our study were also less favorable than those observed in randomized clinical trials. In CATT (Comparison of Age-related macular degeneration Treatments Trial), 1107 patients with wAMD were randomized to intravitreal ranibizumab or bevacizumab and followed over a 2-year period. ${ }^{16}$ The mean gain in letters at year two was greater with monthly than with as-needed treatment $(+8.8$ letters vs +6.7 letters, respectively). The mean number of injections was 22.4 with monthly and
12.6 with as-needed treatment over the 2-year period. In ANCHOR, the mean change in letters was +11.3 letters at year one and +10.7 letters at year two, and the mean number of intravitreal ranibizumab injections was 21.3 over the 2-year period. ${ }^{2}$ In MARINA, mean change in letters was +7.2 letters (year one) and +6.6 letters (year two) (based on $\leq 24$ intravitreal ranibizumab injections over the 2-year period). ${ }^{3}$

We note that our study has a number of limitations inherent to its retrospective and observational design. Our study also failed to reach the target population of 200 patients. Clinical practice may have changed since the study was undertaken, and VAS was monitored using different methods.

\section{CONCLUSION}

In summary, on average, few injections were administered and visual acuity was not improved during the 2-year follow-up in a cohort of patients with wAMD enrolled in our study. Despite a relatively high number of visits, including monitoring visits and use of OCT-guided therapy, the findings indicate that as-needed treatment with intravitreal ranibizumab resulted in suboptimal visual acuity in real-life settings. Such limitations may also be related to an increased number of WAMD patients resulting in clinic saturation coupled with funding constraints within the Portuguese health care system. These limitations are consistent with those published by the Royal College of Ophthalmologists, ${ }^{17}$ which advises that patients requiring long-term follow-up and regular specialist treatment will cause a capacity problem for a health care system, and that a number of approaches may be needed to address the wAMD bottleneck. Tailored advice regarding effective working models for the long-term management of wAMD patients in clinical practice is warranted.

\section{ACKNOWLEDGEMENTS}

Editorial assistance was provided by PAREXEL, which was funded by Bayer. 


\section{PROTECTION OF HUMANS AND ANIMALS}

The authors declare that the procedures were followed according to the regulations established by the Clinical Research and Ethics Committee and to the Helsinki Declaration of the World Medical Association.

\section{DATA CONFIDENTIALITY:}

The authors declare having followed the protocols in use at their working center regarding patients' data publication.

\section{CONFLICTS OF INTEREST}

Rufino Silva has provided consultancy to Allergan, Allimera, Alcon, Bayer, Novartis, and THEA.

\section{REFERENCES}

1. Bloch SB, Larsen M, Munch IC. Incidence of legal blindness from agerelated macular degeneration in denmark: year 2000 to 2010. Am J Ophthalmol. 2012;153:209-13.

2. Brown DM, Kaiser PK, Michels M, Soubrane G, Heier JS, Kim RY, et al. Ranibizumab versus verteporfin for neovascular age-related macular degeneration. N Engl J Med. 2006;355:1432-44.

3. Rosenfeld PJ, Brown DM, Heier JS, Boyer DS, Kaiser PK, Chung CY, et al. Ranibizumab for neovascular age-related macular degeneration. N Engl J Med. 2006;355:1419-31.

4. Cohen SY, Mimoun G, Oubraham H, Zourdani A, Malbrel C, Quere S, et al. Changes in visual acuity in patients with wet age-related macular degeneration treated with intravitreal ranibizumab in daily clinical practice: the LUMIERE study. Retina. 2013;33:474-81.

5. Gallego-Pinazo R, Figueroa MS, Garcia-Layana A. Current state of therapeutic strategies with ranibizumab in neovascular age-related macular degeneration. Curr Opin Ophthalmol. 2015;26:200-5.

6. Holz FG, Tadayoni R, Beatty S, Berger A, Cereda MG, Cortez R, et al. Multi-country real-life experience of anti-vascular endothelial growth factor therapy for wet age-related macular degeneration. $\mathrm{Br} \mathrm{J}$ Ophthalmol. 2015;99:220-6

7. Wolf A, Kampik A. Efficacy of treatment with ranibizumab in patients with wet age-related macular degeneration in routine clinical care: data from the COMPASS health services research. Graefes Arch Clin Exp Ophthalmol. 2014;252:647-55.

8. Ziemssen F, Eter N, Fauser S, Bopp S, Radermacher M, Hasanbasic Z, et al. Retrospektive Untersuchung der Anti-VEGF-Behandlungsrealität und Wirksamkeit bei Patienten mit neovaskulärer altersabhängiger Makuladegeneration (nAMD) in Deutschland. Ophthalmologe. 2015;112:246-54.

9. Hariprasad SM, Morse LS, Shapiro H, Wong P, Tuomi L. Fixed monthly versus less frequent ranibizumab dosing and predictors of visual response in exudative age-related macular degeneration. J Ophthalmol. 2012;2012:690641.
Angelina Meireles, Carla Teixeira, Paulo Rosa, Manuel Monteiro-Grillo, and Joaquim Canelas are consultants to Bayer.

Rita Flores has provided consultancy to Allergan, Allimera, Bayer, and Novartis.

Ângela Carneiro has participated in advisory boards for Alcon, Alimera, Bayer, Allergan, and Novartis.

Carla Gonçalves is an employee of Bayer.

\section{FUNDING SOURCES}

This study was funded by Bayer HealthCare Pharmaceuticals. ClinicalTrials.gov Identifier: NCT01933152.

10. Regillo CD, Brown DM, Abraham P, Yue H, lanchulev T, Schneider S, et al. Randomized, double-masked, sham-controlled trial of ranibizumab for neovascular age-related macular degeneration: PIER Study year 1 . Am J Ophthalmol. 2008;145:239-48.

11. Schmidt-Erfurth $U$, Eldem B, Guymer R, Korobelnik JF, Schlingemann $\mathrm{RO}$, Axer-Siegel $\mathrm{R}$, et al. Efficacy and safety of monthly versus quarterly ranibizumab treatment in neovascular age-related macular degeneration: the EXCITE study. Ophthalmology. 2011;118:831-9.

12. Heier JS, Brown DM, Chong V, Korobelnik JF, Kaiser PK, Nguyen QD, et al. Intravitreal aflibercept (VEGF trap-eye) in wet age-related macular degeneration. Ophthalmology. 2012;119:2537-48.

13. Schmidt-Erfurth U, Kaiser PK, Korobelnik JF, Brown DM, Chong V, Nguyen QD, et al. Intravitreal aflibercept injection for neovascular agerelated macular degeneration: ninety-six-week results of the VIEW studies. Ophthalmology. 2014;121:193-201.

14. Marques IP, Fonseca P, Luz CM, Pires I, Figueira J, Faria de Abreu JR, et al. Treatment of exudative age-related macular degeneration with intravitreal ranibizumab in clinical practice: a 3-year follow-up. Ophthalmologica. 2013;229:158-67.

15. Heimes B, Lommatzsch A, Zeimer M, Gutfleisch M, Spital G, Dietzel $M$, et al. Long-term visual course after anti-VEGF therapy for exudative AMD in clinical practice evaluation of the German reinjection scheme. Graefes Arch Clin Exp Ophthalmol. 2011;249:639-44.

16. Martin DF, Maguire MG, Fine SL, Ying GS, Jaffe GJ, Grunwald JE, et al. Ranibizumab and bevacizumab for treatment of neovascular age-related macular degeneration: two-year results. Ophthalmology. 2012;119:1388-98.

17. Amoaku W. The Royal College of Ophthalmologists: maximising capacity in AMD services: July 2013. The Royal College of Opthalmologists Web site. [accessed 30 April 2015]. Available from: https://www.rcophth.ac.uk/ wp-content/uploads/2014/12/2013-SCI-302-Maximising-Capacity-inAMD-Services-July-2013.pdf. 